\title{
FESTA SOBRE ESCOMBROS: O ATO DE FESTEJAR COMO ESTRATÉGIA DE SOBREVIVÊNCIA À GUERRA
}

\section{CELEBRATING ABOVE THE RUBBLE: THE ACT OF CELEBRATION AS A SURVIVAL STRATEGY IN WAR}

Breno Fernandes

\begin{abstract}
RESUMO: Lançado pela primeira vez com apoio da UNICEF, O diário de Zlata, de Zlata Filipović, é um registro sobre a Guerra da Bósnia (1992-1995), decorrente do desmantelamento da Iugoslávia. A autora, à época, era uma pré-adolescente, habitante de Sarajevo, e é por meio de seu olhar que somos apresentados ao cotidiano da guerra, aos desafios enfrentados diariamente pelas vítimas do conflito e também às estratégias de sobrevivência que elas constroem. Dentre essas estratégias, estăo a própria escrita de um diário e, surpreendentemente, a celebraçăo de festas. Com base nessa constataçâo, o presente artigo propôe uma leitura da valorizaçâo que Zlata dá a essas festas, uma interpretaçăo inspirada em conceitos caros ao trabalho de três teóricos: Georges Didi-Huberman, com a ideia de sobrevivência associada à imagem dos vaga-lumes; Michel de Certeau, atento à invençăo do cotidiano; e Peter Pál Pelbart, que reflete sobre biopolítica, comunidade e o par assujeitamento/soberania.
\end{abstract}

PALAVRAS-CHAVE: Bósnia. Diário. Guerra. Sobrevivência. Zlata Filipović.

ABSTRACT: Initially published under UNICEF's patronage, Zlata's diary, by Zlata Filipović, is a document about the Bosnian War (1992-1995), which took place as a consequence of Yugoslavia's collapse as a nation. The diary was written by a pre-teenage girl who lived in Sarajevo during the war. Through her eyes, readers find out about war routine, the daily challenges faced by war victims, as well as the survival strategies that those people made up. Among many strategies, one may highlights the very act of writing a diary, and, surprisingly, the act of throwing parties. This paper aims to interpret the relevance of these parties to Zlata's life during the war. Such a reading is based on a few concepts developed by three thinkers: Georges Didi-Huberman, who connects the idea of survival to the image of fireflies; Michel de Certeau, who writes about the practice of everyday life; and Peter Pál Pelbart, and his ideas on biopolitics, community, and subjection/sovereignty.

KEYWORDS: Bosnia. Diary. Survival. War. Zlata Filipović. 
Há dois dias foi o aniversário de Avdo (o pai de Lela), mas nesse dia houve bombardeio e nâo pudemos ir. Estou chateadíssima, sâo os únicos dias em que todos os vizinhos podem relaxar um pouco, reunir-se com bom humor. E é mais agradável que nossos encontros habituais... no porăo! É por isso que gosto tanto dos aniversários.

Filipović (1994, p. 91)

\section{INTRODUÇÃO}

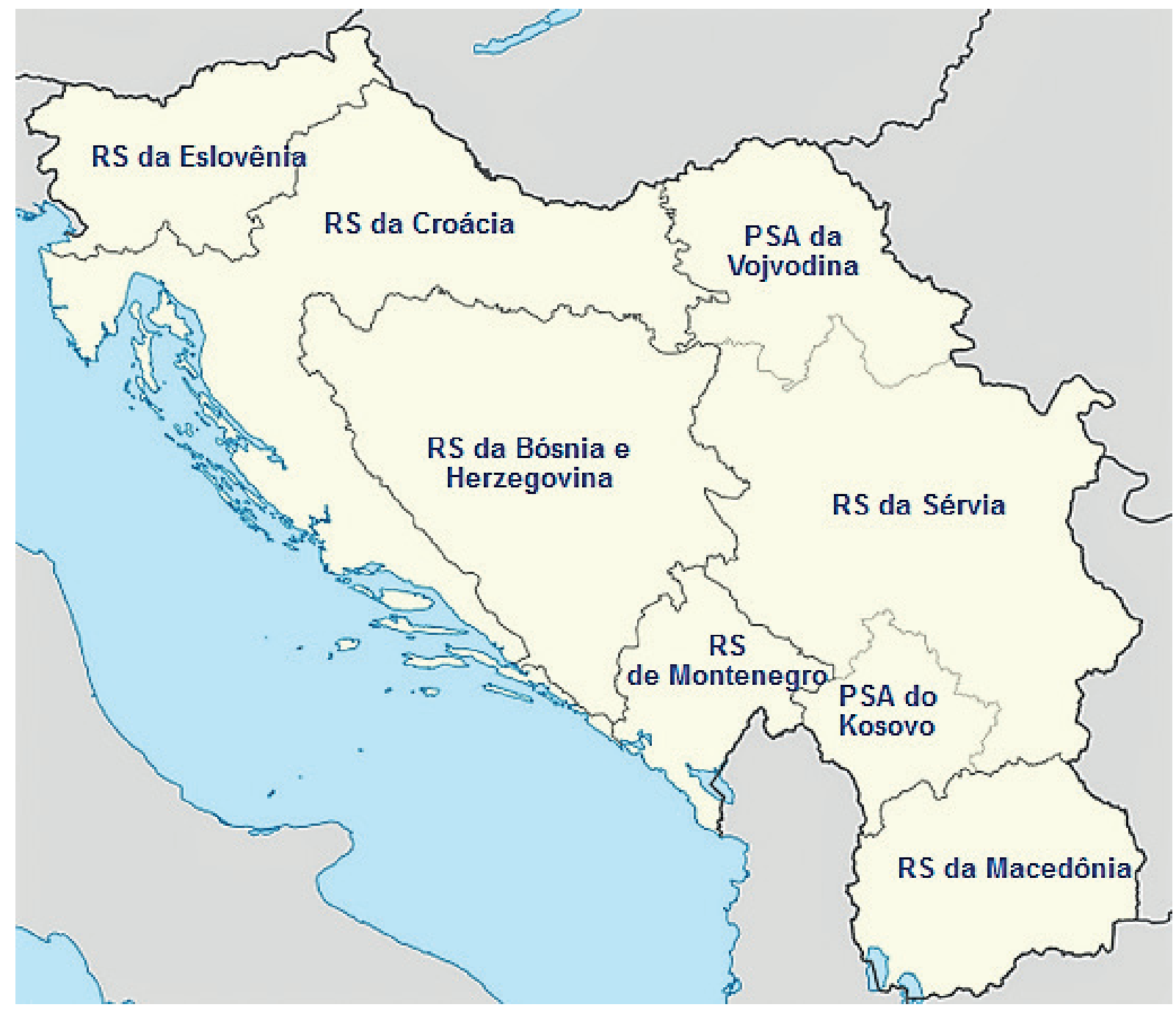

Figura 1 - República Federativa Socialista da Iugoslávia, composta por seis repúblicas. Kosovo e Vojvodina, assinalados no mapa, pertenciam à Sérvia, mas eram regióes autônomas, uma estratégia do marechal Tito para desunificar os sérvios. Extraída de: Wikipédia. 
Os contornos desta história sáo amplamente conhecidos: ${ }^{1}$ era uma vez a Iugoslávia, um país fabricado dos escombros da Primeira Guerra Mundial (19141919), feito de pedaços de impérios que nâo mais existem e de pequenos reinos independentes, todos eles fundidos com a cola identitária do paneslavismo a princípio e, depois, com solda obstinadamente manuseada pelo marechal Josip Broz Tito (1892-1980), que lhes aplicava camadas e mais camadas de uma variaçăo da ideologia comunista que ele próprio chamou de Política de Irmandade \& Unidade.

Mas, após a morte de Tito, seus herdeiros políticos nâo se mostraram interessados em dar continuidade às demáos que manteriam a Iugoslávia uma federaçăo multiétnica, formada por seis repúblicas entăo socialistas - Bósnia e Herzegovina, Croácia, Eslovênia, Macedônia, Montenegro e Sérvia. Em 1991 o desmantelamento teve início: a Eslovênia, a Croácia e a Macedônia declararam independência da Iugoslávia, o que àquela altura era o mesmo que se tornar independente do jugo da Sérvia, o maior e mais poderoso dos Estados iugoslavos, governado por Slobodan Milošević (1941-2006). ${ }^{2}$ Que de modo algum estava disposto a perder inteiramente a zona de influência herdada do marechal Tito, razáo pela qual fomentou o nacionalismo dos sérvios, a maior e mais espraiada etnia da federaçâo. Em outras palavras, Milošević só abriria măo da Iugoslávia se construísse uma Grande Sérvia, anexando territórios das repúblicas vizinhas povoados por seus nacionais. Isso explica os diferentes tratamentos dados às secessōes. Eslovênia e Macedônia, naçōes sem enclaves de gente sérvia, năo tiveram mais do que conflitos pontuais com o poder de Belgrado. Já na Croácia e na Bósnia, houve guerra de fato. A pior delas, na Bósnia, onde um terço da populaçâo era de origem sérvia e onde a disputa territorial logo se transformou em genocídio, em limpeza étnica de um Estado que, havia cerca de cinco séculos, contava com ampla presença de eslavos muçulmanos. ${ }^{3}$

Com três anos e oito meses de duraçâo, de abril de 1992 a dezembro de 1995, a Guerra da Bósnia foi considerada o "mais violento conflito na Europa desde o final da Segunda Guerra Mundial" (LEĀO, 1994, p. 12). Expulsou cerca de 1 milhăo de habitantes do país, a metade da populaçăo, e tirou a vida de 150 mil pessoas, cujos fantasmas nâo deixarâo tâo cedo de assombrar aquela regiăo. E talvez nâo só ela: as tecnologias de comunicaçâo da época foram capazes de registrar proficuamente e de espalhar para o resto do mundo os horrores dessa guerra. Ortiz (1993) chama de cultura-mundo o conjunto de signos, ícones e símbolos que a indústria cultural produz e faz circular entre as diversas comunidades ao redor do globo, mas, quando se tratam das imagens desoladoras, brutais de uma guerra,

1 As informaçôes trazidas neste artigo a respeito do surgimento e do fim da Iugoslávia têm como fonte Burg \& Shoup (1999), Hobsbawm (1995, 2010, 2011a, 2011b), Serva (1994) e o documentário The death of Yugoslavia (1995), produzido pela BBC.

2 Consta em Filipović (1990, p. 16) que, na língua servo-croata, c = ts, ć = tch (suave), č = tch (duro), e = ê, ge = gue, gi = gui, $h=k h, j=i, s=s s, \breve{s}=c h, \breve{z}=j$.

3 Sendo mais específico, a populaçâo étnica da Bósnia à época da guerra, segundo Leâo (1994, p. 10-11), estava dividida em eslavos muçulmanos (41\%), sérvios (30\%) e croatas (17\%), sendo as duas últimas etnias predominantemente cristâs ortodoxas. Os sérvios, ademais, controlavam a maior parte das terras do país. 
difundidas mundialmente, pode ser mais apropriado chamá-las de fantasmas-mundo. Os campos de concentraçâo repletos de seres humanos famélicos. A impiedade materializada sempre que duas pessoas se encontram em extremidades opostas do cano de uma arma e uma delas está de joelhos. O incomensurável pavor das crianças quando notam que mesmo aqueles com cuja proteçâo elas esperam contar estăo com medo. Mesmo daqui do Brasil, um oceano e um continente inteirinhos distante dos Bálcăs, doze anos depois que o Acordo de Dayton ${ }^{4}$ deu cabo ao conflito da Bósnia, ver uma fotografia como a que se apresenta a seguir ainda causa assombro.

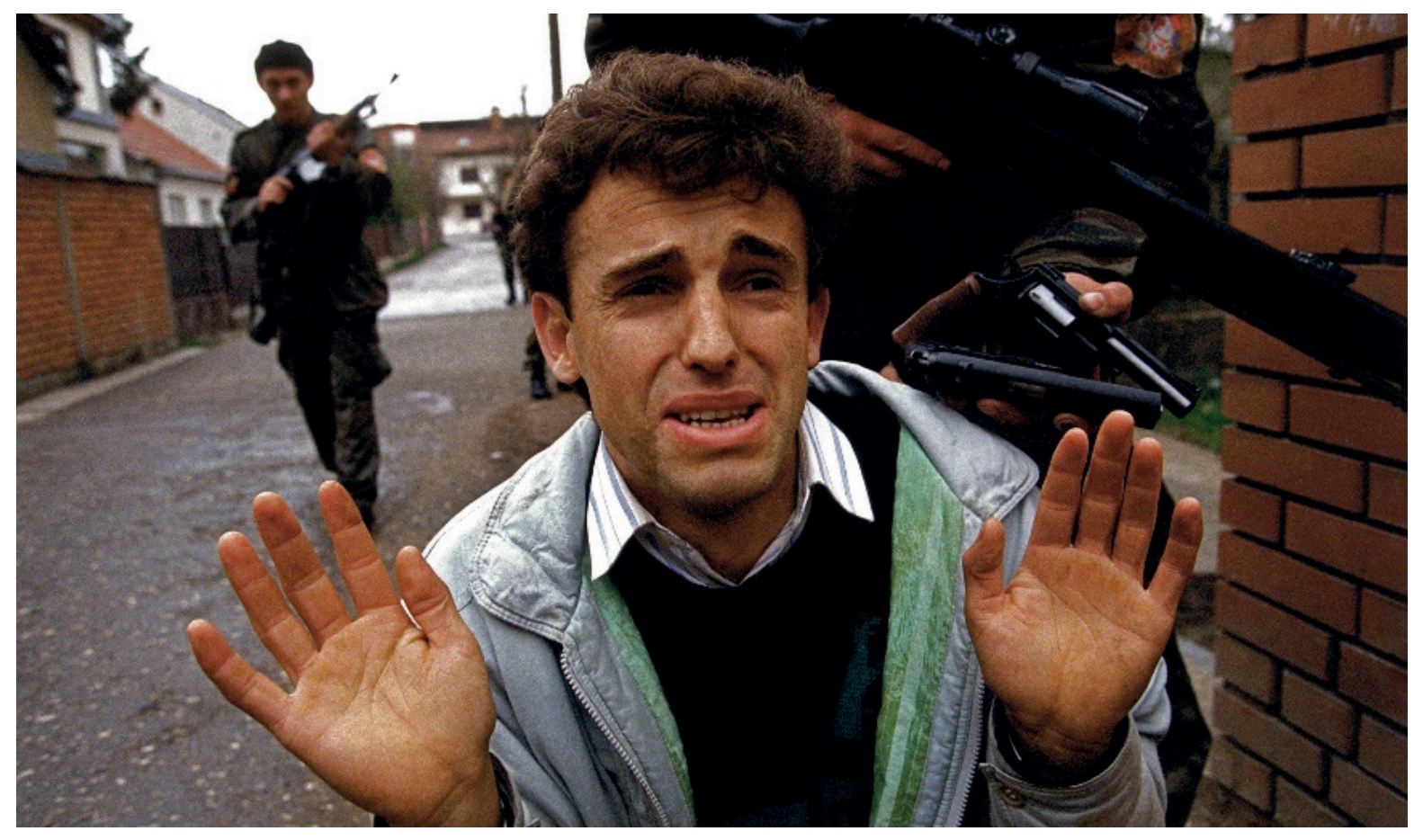

Figura 2 - Hajrush Ziberi, vítima do Massacre de Bijeljina (1992), o primeiro ataque de paramilitares sérvios contra a populaçăo muçulmana da Bósnia. Extraído de: Ron Haviv/Al Jazeera. ${ }^{5}$

4 Em novembro de 1995, na base aérea da cidade norte-americana de Dayton, em Ohio, com intermediaçăo do entâo presidente Bill Clinton, os chefes de Estado da Bósnia e Herzegovina, da Croácia e da Sérvia negociaram os termos de um acordo de paz que seria assinado um mês depois, em Paris, encerrando os conflitos armados nos Bálcâs. Pelo Acordo de Dayton, como ficou conhecido o documento, a Bósnia e Herzegovina se tornou um país dividido em duas entidades políticas: a Federaçáo da Bósnia e Herzegovina, onde a maioria é formada por bósnios muçulmanos e bósnio-croatas; e a República Srpska, de maioria bósnio-sérvia. Desde os primeiros anos do século XXI, pelo menos, nâo é raro encontrar notícias sobre manifestaçôes de grupos favoráveis à independência de Srpska, sinal de que as hostilidades que levaram à guerra outrora seguem existindo.

5 O fotógrafo Ron Haviv foi convidado pelos paramilitares sérvios a registrar seu assalto a Bijeljina. Em 2015, ele escreveu um artigo para o site da Al Jazeera, no qual explicou o contexto em que a foto acima foi feita e contou, ademais, que só 12 anos depois, em 2014, por meio da circulaçấo dessa imagem nas redes sociais, soube que o homem ajoelhado se chamava Hajrush Ziberi e era macedônio. $\mathrm{O}$ corpo de Ziberi foi encontrado no rio Sava, e levou-se 12 anos para que sua identidade fosse descoberta por exames de DNA. Cf. HAVIV, R.'It has begun': a picture of ethnic cleansing in Bosnia. Al Jazeera. [S.I.], 14, mai. 2015. Disponível em: 〈http://bit.ly/1FfakcW〉. Acesso em: 4 out. 2017. 
O presente artigo, no entanto, năo quer tratar da conjuraçăo de fantasmas. Antes, deseja falar de como afujentá-los, destacando algumas estratégias que sujeitos assombrados pela guerra encontraram para enfrentá-la com e em seus corpos. E, por incrível que pareça, esse assunto tem a ver com vaga-lumes, esses bichinhos cuja vida "parecerá estranha e inquietante, como se fosse feita da matéria sobrevivente - luminescente, mas pálida e fraca, muitas vezes esverdeada - dos fantasmas" (DIDI-HUBERMAN, 2011, p. 14). Tem também a ver com festas de aniversário. E com uma pequena história entre as muitas, infinitas pequenas histórias que compóem a grande história da Guerra da Bósnia: a história de uma garotinha chamada Zlata Filipović e de seu diário.

\section{O DIÁRIO DE ZLATA}

No dia 2 de setembro de 1991, uma segunda-feira, em Sarajevo, capital da Bósnia, uma menina de 10 anos está decidida a começar um diário. Caneta e papel em máos, escreve ela:

Atrás de mim, um longo e quente verăo, dias de férias sem pensar em nada; e diante de mim, um novo ano escolar. Vou para a sexta série. Estou impaciente para rever minhas colegas [...]. Estou contente, a gente vai poder falar outra vez da escola e dividir nossas pequenas desgraças e grandes alegrias. (FILIPOVIĆ, 1994, p. 19)

Encontrar de cara o par pequenas desgraças/grandes alegrias, em se considerando os eventos prestes a acontecer, levanta a suspeita de que, com vistas a aumentar o efeito dramático do texto, houve um minucioso trabalho de ediçăo em 0 diário de Zlata, cujo lançamento, em 1993, foi patrocinado pela UNICEF no contexto de seu trabalho humanitário junto às vítimas da Guerra da Bósnia. De toda sorte, essa constataçâo é meramente digressiva, năo desloca o ponto aonde se quer chegar neste arrazoado.

Nos registros seguintes, Zlata nos conta sobre sua rotina de filha única de uma família bósnia de classe média, sem religiosidade manifestada. Escola, aula de piano, aniversários, livros, MTV, o parquinho da vizinhança, fins de semana no casa de campo ou em sua montanha predileta entre as muitas que cercam o vale onde fica Sarajevo tudo isso dá pistas de uma vida prazerosa. Por isso mesmo chama atençâo o qualitativo com que Zlata descreve a primeira vez que a conjuntura política do país afeta explicitamente sua vida. No dia 19 de outubro de 1991, o diário registra:

Um dia infecto, ontem. [...] Quando cheguei da escola, encontrei mamăe chorando e papai de uniforme. Me deu um nó na garganta quando papai anunciou que tinha de ir reunir-se a sua unidade de reserva da polícia porque havia sido chamado. $\mathrm{Me}$ abracei a ele chorando e supliquei para ele năo ir, para ficar conosco. Papai disse que era obrigado a ir. (FILIPOVIĆ, 1994, p. 22-23; grifos nossos)

Ainda năo é o front, o pai de Zlata năo se tornaria um soldado. Fora convocado somente para fazer guarda - náo sabemos se em um local específico ou se nas ruas - em turnos que duravam dez horas, a cada dois dias. Para a garota, entretanto, esse episódio é uma espécie de despertar para a política, para o mundo que existe fora de sua pequena comunidade de afetos ou, melhor ainda, para as forças de submissăo que, vindas de fora, inesperadas, de repente bagunçam a ordem de dentro. A partir do episódio de convocaçăo do pai, comentários sobre açōes governamentais e sobre o clima 
de consternaçăo que Zlata percebe entre os adultos serăo recorrentes no diário, corroborando a imagem de uma infecçăo que começa a se espalhar por um corpo saudável.

A princípio, Zlata faz questăo de marcar sua incompreensăo no que concerne à política, essa entidade alienígena com a qual ela năo deseja se envolver. Em 22 de outubro de 1991, ela escreve: "Alguns reservistas de Montenegro chegaram à Herzegóvina. Por que e para quê? Tudo isso é política e de política eu năo entendo nada. Será que depois de passar pela Eslovênia e pela Croácia, os ventos da guerra văo soprar na BósniaHerzegóvina?" (FILIPOVIĆ, 1994, p. 23). Em 14 de novembro: "Papai e mamáe passam o tempo todo assistindo o noticiário pela tevê. Estăo preocupados. [...] Eles e os amigos discutem principalmente política. O que é política? Năo faço a menor idéia. E depois, isso é uma coisa que năo me interessa tanto" (FILIPOVIĆ, 1994, p. 27). Já em 5 de março de 1992, cerca de um mês antes de a violência armada tomar conta de Sarajevo, surpresa!, encontramos a descriçăo interessada de um debate envolvendo figuras públicas:

[...] uma multidăo se reuniu na Frente da Iutel [rede de televisăo iugoslava]. Radovan Karadžič e Alija Izetbegovič tomaram a palavra e brigaram. Aí Goran Milić ficou bravo e obrigou os dois a encontrarem um certo general Kukanjac.

Esse Milić é demais! Bravo!!!

Quarta-feira (4 de março) as barricadas foram retiradas e esses "moleques" entraram num acordo. (FILIPOVIĆ, 1994, p. 40) 6

Neste trecho, salta aos olhos o uso da palavra moleques, sobre a qual, em nota da própria Zlata, nos é dado saber que se tratava de um apelido que as pessoas davam aos políticos. Se é certo que apelidos pressupóem alguma intimidade, entâo, seis meses depois de a menina vislumbrar pela primeira vez o poder da política sobre as pessoas, e de buscar uma espécie de fuga desse poder pela incompreensăo, um agarrar-se à inocência, ela parece ter aceitado que era inevitável participar, se quisesse trazer sua velha rotina de volta. Pode-se inferir essa motivaçâo no parágrafo seguinte à descriçâo do bate-boca entre os moleques, quando Zlata conta que, no dia da celebraçâo do Dia Internacional da Mulher na escola, uma festa de destaque nos países do Leste, foi pedido que os alunos voltassem para casa. "Problemas outra vez. Todo mundo entrou em pânico. As meninas começaram a berrar enquanto os meninos piscavam em silêncio. Papai também voltou mais cedo" (FILIPOVIĆ, 1994, p. 40).

Quando a guerra eclode na cidade, no início de abril de 1992; quando as montanhas ao redor de Sarajevo ficam apinhadas de paramilitares sérvios que, nas palavras de Zlata, fazem trovejar sobre as pessoas lá embaixo; quando as aulas sâo suspensas e os pais, dispensados de seus trabalhos; quando edifícios públicos sáo incendiados ou bombardeados; quando a populaçấo começa a fugir em peso da cidade; quando é preciso passar as noites em um porăo "feio, todo escuro e [que] tem um cheiro horrível" (FILIPOVIĆ, 1994, p. 52); quando se fica sem luz, sem aquecimento, quase sem comida; quando "[a]s granadas caem, das grandes, crianças săo mortas, disparam de todos os lados" (FILIPOVIĆ, 1994, p. 50); quando, enfim, o fantasma da guerra "entrou de repente

60 muçulmano Alija Izetbegovič era o entăo presidente da Bósnia. Radovan Karadžič, por sua vez, era o líder da comunidade dos sérvios naquele país. Goran Milić, um célebre jornalista local, e o general

Kukanjac comandava o braço do exército iugoslavo lotado em Sarajevo no começo da guerra. 
em nossa cidade, em nossa casa, em nossas cabeças, em nossas vidas" (FILIPOVIĆ, 1994, p. 48-49); quando tudo isso acontece, começa para Zlata um outro modo de fazer política. Nada protocolar, năo institucional; ainda assim, com o mesmo objetivo de toda forma de política: agir sobre uma camada da realidade social.

Pelbart (2003) chama essa política de biopolítica. Como é sabido, o conceito foi criado por Michel Foucault para designar a "entrada do corpo e da vida, bem como de seus mecanismos, no domínio dos cálculos explícitos do poder" (PELBART, 2003, p. 24), "a perspectiva do poder e de sua racionalidade refletida tendo por objetivo passivo o corpo da populaçâo e suas condiçóes de reproduçăo, sua vida" (PELBART, 2003, p. 24). Pelbart (2003) prefere uma releitura desse conceito, que trata a biopolítica menos como "o poder sobre a vida" e mais como "a potência da vida" (PELBART, 2003, p. 25). Vida, aqui, significando "inteligência, afeto, cooperaçăo, desejo" (PELBART, 2003, p. 25).

Nesse contexto, entende-se que a biopolítica de Pelbart (2003) se aproxima harmoniosamente da política das sobrevivências, de Didi-Huberman (2011). Uma política que "se encarnaria nos corpos, nos gestos e nos desejos de cada um" (DIDI-HUBERMAN, 2011, p. 24-25). E que encontra sua alegoria perfeita nos vaga-lumes, esses "seres luminescentes, dançantes, erráticos, intocáveis e resistentes enquanto tais" (DIDIHUBERMAN, 2011, p. 23), pois que os vaga-lumes nos fariam

[...] repensar nosso próprio "princípio esperança" através do modo como o Outrora encontra o Agora para formar um clarăo, um brilho, uma constelaçăo onde se libera alguma forma para nosso próprio Futuro. Ainda que beirando o chăo, ainda que emitindo uma luz bem fraca, ainda que se deslocando lentamente, năo desenham os vaga-lumes, rigorosamente falando, uma tal constelaçăo? (DIDI-HUBERMAN, 2011, p. 60)

No mundo fantasmagórico da guerra, um mundo de breu e de escombros, é preciso buscar os vaga-lumes, por mais difícil ou penoso que seja atentar-se a sua "luz pulsante, passageira, frágil" (DIDI-HUBERMAN, 2011, p. 44). É preciso "observá-los no presente de sua existência", "vê-los dançar vivos no meio da noite, ainda que essa noite seja varrida por alguns ferozes projetores" (DIDI-HUBERMAN, 2011, p. 52) ou projéteis de brilho apocalíptico. Entăo veremos que a potência da vida é incomensurável mesmo em suas formas mais miúdas. E nos lembraremos de que "a destruiçăo nunca é absoluta" (DIDI-HUBERMAN, 2011, p 84).

Para Zlata, a própria escrita de um diário é um ato de biopolítica, uma política de sobrevivência, a invocação de vaga-lumes para afujentar os fantasmas da guerra. Em 5 de julho de 1992, ela anota: "Passo o tempo todo em casa e no porăo. E assim transcorre minha infância de guerra. Estamos no verăo. As outras crianças estáo passado férias no mar, na montanha, nadam, tomam sol, se divertem" (FILIPOVIĆ, 1994, p. 78). Zlata, enquanto isso, escreve. E, pela escrita, "[s]em sair do lugar onde tem que viver e que lhe impóe uma lei", a lei da guerra, ela "instaura pluralidade e criatividade" em seu espaço de confinamento (CERTEAU, 1998, p. 93). Se "[o] lápis da guerra [...] só sabe escrever duas palavras: infelicidade e morte" (FILIPOVIĆ, 1994, p. 103), a garota Zlata pode mais.

Também pela escrita, ela reinstaura a socialidade. A suspensâo das atividades escolares e a migraçăo de seus amigos de longa data năo chega a privar a garota de ter contato com outras crianças, haja vista o considerável fluxo de famílias que, em rota de fuga, se refugiam, por intervalos de tempo variados, na vizinhança de Zlata. 
Mas Mimmy, como ela passa a chamar seu diário, motivada pelo fato de Anne Frank ${ }^{7}$ haver adotado a mesma prática de personificaçăo, Mimmy é a única companhia, para além de seus pais, a seguir com a garota em todos os momentos, fonte de estabilidade e disponibilidade.

Já adulta, prefaciando uma compilaçăo de diários de guerra escritos por crianças, da qual é coorganizadora, a própria Zlata avalia a importância de escrever durante uma situaçâo como a que ela vivenciou:

\begin{abstract}
[...] os diários [...] propicipam aos seus autores um refúgio da loucura que os cerca e se tornam espaços de comunicaçăo e expressâo pessoal. Os diários săo ao mesmo tempo registros e confissōes, enquanto a escrita é um método de transformaçăo, permitindo aos autores assimilar e personalizar os eventos que os cercam e estăo fora de seu controle. Durante o conflito, o mundo exterior é forte e incontrolável; a morte espreita em cada esquina e a todo momento, e entáo a criaçáo desse espaço pessoal e íntimo que um indivíduo pode dominar e utilizar para dar algum sentido à própria vida torna-se incrivelmente importante. Através da observaçăo e da escrita, o autor do diário também vivencia uma maneira de se distanciar da situaçăo terrível, mesmo que seja apenas pela duraçáo da escrita. (FILIPOVIĆ, 2008, p. 16)
\end{abstract}

Essa reflexăo remete, invariavelmente, à ideia foucaultiana da escrita de si como cuidado de si. Klinger (2006), ao retomar esses conceitos para pensar o narrador contemporâneo, trata a escrita de si, o falar de si, como a busca de um efeito de real. Todavia, quando o real é a guerra, esse tipo de escrita se coaduna muito mais com o que Certau (1998) chama de táticas desviacionistas - um desvio, neste caso, do próprio real-breu.

Obviamente, a escrita nâo é a única tática desviacionista disponível, seja ela tomada como ato específico ou como metonímia da arte. Na leitura de O diário de Zlata, outras estratégias de sobrevivência sâo verificadas: da brincadeira ao estudo, da música ao teatro, percebemos que, na guerra, "[o] cotidiano se inventa com mil maneiras de caça nâo autorizada" (CERTEAU, 1998, p. 38) aos vaga-lumes. E uma das que mais chama atençăo, por todas as evocaçōes que o termo nos traz e que parecem tăo deslocadas no contexto da guerra, é a festa; o empenho de festejar mantido por aquela pequena comunidade de vizinhos e familiares de Zlata, que com frequência passam os dias trancafiados em casa e, à noite, dormem em poróes, ouvindo o trovejar das montanhas. É sobre esse empenho que se comenta a seguir.

\title{
FESTEJAR PARA SOBREVIVER
}

Refletindo acerca da comunidade, Pelbart (2003) vai de encontro a uma narrativa bastante difundida e bastante nostálgica, idealizadora do passado: a ideia de que, "onde há sociedade, perdeu-se a comunidade" (PELBART, 2003, p. 31); a crença em que nossos ancestrais, mais sortudos do que nós, puderam experimentar uma comunhâo gloriosa, natural, na qual, entre a família nuclear e o grupo maior, năo havia distinçăo, somente

7 Antes mesmo da publicaçăo de seu diário, quando descobriram que a garota o escrevia, a imprensa passou a se referir frequentemente a Zlata como a Anne Frank de Sarajevo - um epíteto que, convenhamos, năo poderia ser mais indelicado. "Me comparam com Anne Frank. E isso me dá medo, Mimmy", escreve ela no dia 2 de agosto de 1993. "Tenho medo de acabar como ela" (FILIPOVIĆ, 1994, p. 155). 
gradaçăo. Pelbart (2003) prefere ver a comunidade como um espaço relacional a ser construído no âmbito da vida em sociedade, "feit[o] da interrupçáo, fragmentação, suspense, [...] feit[o] dos seres singulares e seus encontros" (PELBART, 2003, p. 33; grifo nosso). Portanto a comunidade é provisória, é o que acontece em "momentos e estados difusos e subjetivos, [...] de gratuidade milagrosa" (PELBART, 2003, p. 35), quando podemos existir de maneira soberana, isto é, "independente de qualquer utilidade, [...] de qualquer necessidade, de qualquer finalidade" (PELBART, 2003, p. 34). E falar de soberania aqui nos interessa na medida em que "[o] soberano é o oposto do [...] assujeitado, seja à necessidade, ao trabalho, à produçăo, ao acúmulo, aos limites ou à própria morte" (PELBART, 2003, p. 34; grifo nosso).

Exemplo de encontro gratuito que chama atençăo em O diário de Zlata săo os festejos que as pessoas seguem promovendo durante a guerra em Sarajevo. Há registros de festas de aniversário e de casamento, celebraçōes de Natal e de réveillon, e até festins improvisados, como quando, depois de a energia ser cortada, no segundo mês de guerra, os Filipović decidiram chamar os vizinhos - a família Bobar, de cujo porăo Zlata e seus pais se valiam - e realizar um banquete, mesmo sabendo que "[e]ncontrar comida em Sarajevo está virando realmente um problema" (FILIPOVIĆ, 1994, p. 63).

Papai encontrou um velho fogáo a lenha no sótăo. É tăo velho que é divertido. No porăo encontramos madeira, os Bobar também. Instalamos o fogăo no pátio interno e cozinhamos toda a comida que estava na geladeira. Os Bobar vieram nos ajudar, fizemos um banquete. No cardápio [...] tinha de tudo. (FILIPOVIĆ, 1994, p. 63)

Desde esse dia, o hábito de cozinhar juntos foi incorporado às práticas de vizinhança. Pode-se defender que a aura festiva de qualquer evento se desgasta com a rotina, mas se trata mais de desvanecimento do que de completa desapariçăo. Prova disso é o seguinte registro do dia 14 de agosto de 1992:

Ontem à noite, como de hábito e como todas as noites, os Bobar vieram para nossa casa para ouvir a RFI. Bojana e eu estávamos jogando cartas. Todo mundo estava relaxado e por um momento esquecemos que estamos em guerra. Lá pelas 21 h30 as explosóes de granada recomeçaram. De repente, como acontece tantas vezes. Fomos correndo para o apartamento de Nedo. Lá pela meia-noite os tiros diminuíram e pudemos voltar para casa. Relaxar... năo podemos relaxar de jeito nenhum! (FILIPOVIĆ, 1994, p. 82; grifos nossos)

A despeito do tom pessimista do final desse registro, nota-se que as noitadas habituais entre os Filipović e os Bobar sâo de fato um momento de encontro que a Zlata oferecem, no mínimo, uma distraçáo nas noites escuras, preenchendo com ludicidade e socialidade horas que poderiam ser somente longas e angustiantes esperas pela chuva de granadas, vigílias no escuro. Sem os vaga-lumes das noites de cartas, a Zlata restaria o brilho dos tiros no negrume a seu redor.

E, se simples soirées sâo capazes de atrair vaga-lumes, que dizer das noites especiais, como aquela na qual houve a comemoraçăo das bodas de amigos...

Hoje Alma e Dado festejaram seu aniversário de casamento. Nosso presente foi um porta-guardanapos e uma gravata. A festa e o bolo estavam demais! (FILIPOVIĆ, 1994, p. 87) 
... ou aquela quando festejaram, em Sarajevo, um casamento que estava acontecendo em outro país, as núpcias de um amigo que conseguira emigrar...

Hoje Nedo se casa. Isso mesmo, o nosso Nedo [...].

Fizemos uma festinha em homenagem ao casamento dele. Mamáe fez um bolo (ouviu bem? um bolo) em forma de coraçăo. Delicioso. Tia Boda e Alemka prepararam todo o resto - enfim, o que é possível preparar com essa guerra [...]...

Nos reunimos em casa de tia Boda. Nedo e Amna estavam em Viena. Mas em pensamentos estávamos com eles e lhes transmitimos todos os nossos votos de felicidades. Fizemos de conta que estávamos num casamento, Mimmy, numa vida onde se faz de conta. Como todo o tempo em Saravejo. Brincamos de fazer de conta que estamos vivendo para que fique mais fácil. (FILIPOVIĆ, 1994, p. 162)

... ou, ainda, da noite de Natal?

Estamos no Natal. Um Natal de guerra. De todo modo as pessoas tentaram fazer uma bonita festa para as crianças.

Tia Radmila havia colocado meu nome na lista das crianças da Caritas. E graças a ela fui ver o show de Natal na sede da FORPRONU [Força de Proteçăo das Naçôes Unidas], no correio central. [...]

No show havia Tifa, Gogá Magaš, cinco garotas e um garoto que dançaram um negócio imbecil antes de fumar um cigarro. Alma, a que passa o tempo todo fazendo Uauaaá!... quando canta, mais as outras estrelas. Depois, chegaram os presentes e as gulodices. [...] Depois, os soldados franceses cantaram. Fantástico. (FILIPOVIĆ, 1994, p. 162)

Mas, de todas as festas mencionadas em $O$ diário de Zlata, aquelas de que a garota mais desfruta sâo os aniversários. É claro que, no início, para ela é difícil lidar com a celebraçấo da vida ao som de explosôes e com imagens de cadáveres gravadas na retina. Isso se evidencia no relato do primeiro aniversário em meio à guerra, em junho de 1992, dois meses depois que a violência estourara em Sarajevo:

Hoje é aniversário de Maja. Ela está fazendo dezoito anos. Agora é maior de idade. Ficou adulta. Para Maja é um dia importante, e veja como ela o celebrou: na guerra. Todos nós tentamos fazer o possível para que este fosse um grande dia para ela, mas Maja estava triste, emburrada. Esta guerra veio estragar tudo. (FILIPOVIĆ, 1994, p. 64)

Em setembro do mesmo ano, no entanto, o tom dos relatos em relaçăo aos aniversários muda. No dia 8 , a aniversariante é sua mâe. No dia 12 , sua tia é quem comemora. No dia 17, sua vizinha e amiga, Alma. E mesmo que, no dia 15, um garoto com quem ela fazia aulas de teatro tenha morrido, vítima de uma granada; e ainda que o aniversário de Alma pudesse ter sido "muito melhor se aquela granada năo tivesse vindo estragar tudo" (FILIPOVIĆ, 1994, p. 88); a despeito de tudo isso, no dia 18, Zlata confessa a Mimmy, seu diário: "Você está vendo, a gente presta atençâo na lista dos aniversários e tenta esquecer a guerra" (FILIPOVIĆ, 1994, p. 88). Esse ato, de acompanhar e participar dos aniversários, é de fato uma estratégia de sobrevivência, e Zlata parece compreendê-lo, tanto que, cinco meses depois, em fevereiro de 1993, ela torna a repetir: "Adoro aniversários, pois eles me lembram a paz (claro, quando náo há tiros de canhâo)" (FILIPOVIĆ, 1994, p. 122). 
A importância que Zlata dá aos aniversários năo se nota só por comentários reflexivos sobre o assunto. Sua reaçăo à impossibilidade de se comemorar um deles, por causa de bombardeios que a deixaram trancada em casa, também evidencia o quanto essas festas săo caras à menina:

Estou chateadíssima, sáo os únicos dias em que todos os vizinhos podem relaxar um pouco, reunir-se com bom humor. E é bem mais agradável que nossos encontros habituais... no porăo! É por isso que gosto tanto dos aniversários. (FILIPOVIĆ, 1994, p. 91)

Esse relaxamento, esse bom humor, esse encontro fora da escuridāo dos porōes, que Zlata tanto aprecia nos aniversários em meio à guerra, fazem pensar no que Pelbart (2003) diz a respeito do corpo que nâo aguenta mais - "năo aguenta mais tudo aquilo que o coage, por fora e por dentro" (PELBART, 2003, p. 45). Efetivamente, Pelbart (2003) está tratando nietzschianamente do corpo que é adestrado, disciplinado, impotencializado pelo civilizatório. E, contra isso, o antídoto seria "retomar o corpo naquilo que lhe é mais próprio, sua dor no encontro com a exterioridade, sua condiçăo de corpo afetado pelas forças do mundo" (PELBART, 2003, p. 45). Explica-nos Pelbart (2003) que "todo sujeito vivo é primeiramente um sujeito afetado, um corpo que sofre de suas afecçōes, de seus encontros, da alteridade que o atinge, da multidâo de estímulos e excitaçôes" (PELBART, 2003, p. 45). Por meio de escolhas, evitamentos e acolhimentos, poderíamos buscar ser mais e melhor afetados, desviando-nos daquilo que nos ameace em demasia. Obviamente, quando se está como Zlata, em meio à guerra, presa dentro de uma zona de violência extrema, na qual se pode morrer por qualquer descuido ou mesmo em se tomando todos os cuidados possíveis, essa filtragem de afecçōes é enormemente limitada, as forças do mundo sâo por demais destrutivas, a sensaçăo de corpo que nâo aguenta mais decerto alcança níveis alarmantes, o pico da escala de riscos à autopreservaçăo. Ainda assim, impressiona ver como, na invençăo do cotidiano, descobre-se potência mesmo naqueles corpos que parecem mais impotentes ou impotencializados, vivendo em meio a escombros. Impressiona ver como, no encontro uns com os outros, ou seja, na comunidade, esses corpos conseguem se fazer soberanos, a nada assujeitados, invencíveis - ainda que pela duraçâo de um lampejo. E isso năo é pouco. Mais uma vez, vale citar Didi-Huberman (2011) quando escreve: "Ainda que beirando o chăo, ainda que emitindo uma luz bem fraca, ainda que se deslocando lentamente, năo desenham os vaga-lumes, rigorosamente falando, uma tal constelaçăo?" (DIDI-HUBERMAN, 2011, p. 60).

O poder do lampejo năo deve ser subestimado. Lendo Spinoza (2009) - cujas ideias alicerçam as teorias das afetos, bastante em voga hoje em dia -, por vezes se tem a impressâo de que seus dois afetos básicos, a alegria e a tristeza, se equivalem em poder. Dito de outro modo, pareceria possível manter o sujeito entre dois pontos específicos se nele se alternassem uma mesma quantidade de experiências de tristeza e de alegria. No entanto as festas ocasionais que a comunidade de Zlata celebra sugerem que a alegria, ainda que em pequenas doses, tem potência maior, capaz de fazer um corpo que năo aguenta mais aguentar um tiquinho mais, sobreviver a mais uma noite no porăo.

A comunidade em festa é uma constelaçăo de vaga-lumes. 


\section{CONSIDERAÇÕES FINAIS}

Aos olhos da pequena Zlata, a guerra parece ser uma manifestaçâo do leviată hobbesiano. Como se escapa de um monstro tăo poderoso, que quando se ergue é capaz de ocultar o sol? Na noite que ele provoca, despertam-se outras criaturas das trevas, a exemplo dos fantasmas, que circulam pelo caos do que até um segundo antes de o leviatâ estalar sua cauda feito chicote era edificaçăo e depois virou ruína. Săo esses monstros menores aqueles que podem efetivamente nos encontrar em nossos esconderijos. Como se escapa dos fantasmas da noite?

É preciso, suponho, devir vaga-lume; aprender sua "potência de nos acenar na noite" (DIDI-HUBERMAN, 2011, p. 30); buscar em nossos corpos humanos - e "um corpo é primeiramente encontro com outros corpos" (PELBART, 2003, p. 46) -, buscar no encontro, na comunidade, a potência capaz de nos acender "seu lampejo e a esperança intermitentes" (DIDI-HUBERMAN, 2011, p. 130), de nos permitir emular "o voo incerto dos vaga-lumes" (DIDI-HUBERMAN, 2011, p. 14) e, quem sabe assim?, dotados dessa leveza, ainda que ela seja insustentável no final das contas, e com o brilho efêmero que produzimos a nos guiar, quem sabe assim?, mesmo vivendo em meio às ruínas e dormindo sob elas, com medo das bombas, possamos em algum momento festejar sobre os escombros. 


\section{REFERÊNCIAS}

BURG, S. L.; SHOUP, P. S. The war in Bosnia-Herzegovina: ethnic conflict and international intervention. Londres, Nova Iorque: Routledge, 1999. p. 169-188.

CERTEAU, M. d. A invençâo do cotidiano: artes de fazer. Traduçăo Ephraim Ferreira Alves. 3. ed. Petrópolis: Editora Vozes, 1998. p. 37-106.

DIDI-HUBERMAN, G. Sobrevivência dos vaga-lumes. Traduçăo Vera Casa Nova e Márcia Arbex, revisâo Consuelo Salomé. Belo Horizonte: Editora UFMG, 2011.

FILIPOVIĆ, Z. O diário de Zlata: a vida de uma menina na guerra. Traduçăo Antonio de Macedo Soares e Heloisa Jahn. Sáo Paulo: Companhia das Letras, 1994.

FILIPOVIĆ, Z. Introduçăo: In: FILIPOVIĆ, Z.; CHALLENGER, M. (Org.). Vozes roubadas: diários de guerra. Traduçăo Augusto Pacheco Calil. Săo Paulo: Companhia das Letras, 2008. p. 13-19.

HOBSBAWM, E. Era dos extremos: o breve século XX. Traduçăo Marcos Santarrita, revisāo técnica Maria Célia Paoli. Sáo Paulo: Companhia das Letras, 1995.

HOBSBAWM, E. A era das revoluçóes, 1789-1848. Traduçăo Maria Tereza Teixeira e Marcos Penchel. 25. ed. São Paulo: Paz e Terra, 2010.

HOBSBAWM, E. A era do capital, 1848-1875. Traduçăo Luciano Costa Neto. 15. ed. Sâo Paulo: Paz e Terra, 2011a.

HOBSBAWM, E. A era dos impérios, 1875-1914. Traduçâo Sieni Maria Campos e Yolanda Steidel de Toledo. 13. ed. Săo Paulo: Paz e Terra, 2011b.

KLINGER, D. I. A escrita de si (o retorno do autor). In: Escritas de si, escritas do outro: autoficçâo e etnografia na narrativa latino-americana contemporânea. 2006. 204 f. Tese (Doutorado em Literatura Comparada) - Doutorado em Letras: Universidade do Rio de Janeiro, Rio de Janeiro, 2006. p. 16-67.

ORTIZ, R. Cultura e mega-sociedade mundial.Lua Nova, n. 28-29, p. 283-296, 1993. Disponível em: <http://dx.doi.org/10.1590/S0102-64451993000100014>. Acesso em: 11 abr. 2015.

PELBART, P. P. Parte I: a vida (em) comum. In: Săo Paulo: Iluminuras, 2003. p. 17-51. . Vida capital: ensaios de biopolítica.

SERVA, L. Prefácio. In: FILIPOVIĆ, Z. O diário de Zlata: a vida de uma menina na guerra. Săo Paulo: Companhia das Letras, 1994. p. 5-14.

SPINOZA, B. d. A origem e a natureza dos afetos. In: . Ética. Traduçăo Tomaz Tadeu. Belo Horizonte: Autêntica, 2009. p. 95-152.

THE DEATH of Yugoslavia. Direçăo: Angus MacQueen, Paul Mitchell. Produçăo: Brian Lapping, Nicholas Fraser, Norma Percy, Tihomir Loza. [S.I.]: BBC, 1995. 6 arquivos digitais (294 min.), son., col. 